\section{Fin metodebok for skadepoliklinikk}

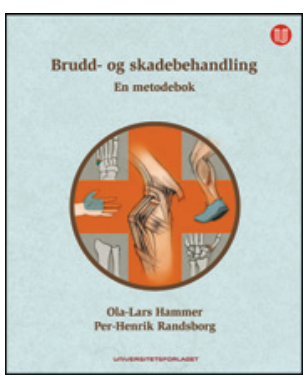

Ola-Lars Hammer, Per-Henrik Randsborg Brudd- og skadebehandling

En metodebok. 266 s, ill. Oslo:

Universitetsforlaget, 2014. Pris NOK 499

ISBN 978-82-15-02011-2
Målgruppen er leger som arbeider med akutte skader, enten i akuttmottak, på legevakt eller legekontor.

Det er tre hovedkapitler. Del 1 er på omtrent 120 sider og omtaler skader hos voksne. Del 2 omhandler skader hos barn og er på omtrent 75 sider. I den siste delen tar forfatterne for seg diverse sår og sårskader, brannskader, abscesser, lokalbedøvelse med mer. Det er også et eget kapittel om brudd og gipseteknikk.

Del 1 og 2 er logisk oppbygd med kapittelinndeling etter skadet anatomisk lokalisasjon (overekstremitet, underekstremitet, hode, hals, columna, og deretter thorax, buk og perineum). Del 3 er mer å anse som et oppsamlingskapittel uten åpenbar indre sammenheng. Hver enkelt skade er systematisk og kortfattet beskrevet med bakgrunn og skademekanisme, kliniske funn, tiltak og oppfølging. Boken er rikt illustrert med typiske røntgenbilder for de ulike skadene. Den har også rikelig med fine skisser og tegninger som bidrar til å gjøre innholdet lettfattelig.

De ulike brudd og luksasjoner, med indikasjon for operativ behandling og gipsetider, er ganske detaljert beskrevet og omfatter omtrent halve boken. Både operasjonsindikasjon og gipsetid vil nok variere litt avhengig av behandlingssted.

Noen opplysninger er utdaterte. Blant annet gjentas advarselen mot bruk av adrenalintilsetning til lokalbedøvelse av fingre og tær og de tradisjonelle tidsgrensene ( 8 og 24 timer) ved lukking av traumatiske hudsår. Legemiddelverkets advarsel mot bruk av kodeinholdige preparater til barn under 12 år fremkommer ikke.

Dette er en fin metodebok som egner seg godt til daglig bruk for turnusleger og leger i spesialisering ved skadekirurgiske poliklinikker. Detaljrikdommen om brudd og bruddbehandling er imidlertid såpass omfattende at den er mindre egnet til daglig bruk ved de fleste legevakter. Her egner den seg best som oppslagsverk.

\section{Knut Steen}

Overlege, Bergen legevakt

Oppgitte interessekonflikter: Anmelder har revidert tre kapitler i Legevakthåndboken.

\section{Rom for refleksjon?}

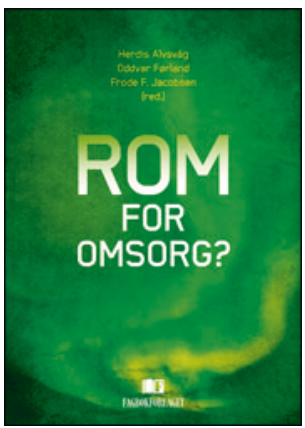

Herdis Alvsvåg, Oddvar Førland,

Frode F. Jacobsen, red.

Rom for omsorg?

300 s. Bergen: Fagbokforlaget, 2014.

Pris NOK 399

ISBN 978-82-450-1603-1

Denne boken handler om rom for omsorg, der «rom» er nærmere spesifisert som vilkår, relasjoner og omgivelser for omsorg. Det er en antologi med kapitler skrevet av 18 forfattere, alle sentrale personer fra omsorgsforskning og sykepleievitenskap.

På baksiden står det at målgruppen er studenter i helse- og sosialfag ved høgskoler og universiteter og ansatte i helse- og omsorgstjenestene. Boken må således oppfattes som en lærebok. Som sådan antas den å skulle formidle kunnskaper, verdier og holdninger til bruk i et fremtidig yrke. Undertegnede er altså ikke i målgruppen, men har fått boken til anmeldelse som vanlig leser.

Jeg har tidligere lest arbeider av flere av kapittelforfatterne med stor interesse. Denne gang var det imidlertid tungt stoff. En rekke av elementene som inngår i mellommenneskelig omsorg er problematisert og gjennomdiskutert, ofte med utgangspunkt i kjente filosofers og samfunnsviteres tanker og teorier. Litteraturlistene er omfattende, selv om det ikke alltid er lett å se hva som er varianter av det samme, eller tekster som bygger på hverandre. Rammeverket for å yte og å motta omsorg drøftes i detalj. Det er mye å tenke videre på.

En student vil sannsynligvis konsentrere seg om å tilegne seg det som står. En leser som ikke er under eksamenspress, vil kanskje tenke annerledes. Eksempel: Når det i flere kapitler henvises til den danske teologen og filosofen Knud Ejler Løgstrup (1905-81) og hans tilhengere, skjerpes interessen for hva andre har sagt og ment om de samme temaene. Leseren føler det som om boken representerer en «skole» innen omsorgsfagene, med et profesjonsbyggende siktemål.

Boken bygger opp et teoretisk fundament også for slike omsorgstanker og omsorgshandlinger som springer ut av normal mellommenneskelighet. Det er bra. Teoretisering kan imidlertid også føre til distanse. Jeg kan begynne å spekulere: Når en omsorgsperson er hyggelig og omtenksom mot meg når jeg trenger det, er det fordi vedkommende mener det som sies? Eller fordi det er tillært? I så fall vil jeg betakke meg, på samme måte som jeg nødig vil bli gjenstand for den såkalte kroppslige velværeberøringen som et av kapitlene omtaler.

Det er mye refleksjon mellom permene her. Men jeg synes ikke antologien som sådan gir leseren tilstrekkelig rom for selvstendig, uavhengig refleksjon. Den er for normativ for meg.

\section{Øivind Larsen}

Professor emeritus, Institutt for helse og samfunn

Universitetet i Oslo

Oppgitte interessekonflikter: Anmelder er redaktør i tidsskriftet Michael som har publisert artikler av enkelte av forfatterne i boken som her anmeldes. 